\title{
Ranging behaviour of non-breeding Eurasian Griffon Vultures Gyps fulvus: a GPS-telemetry study
}

\author{
Clara GARCíA-RIPOLLÉS ${ }^{1}$, Pascual LóPEZ-LÓPEZ ${ }^{1}$ \& Vicente URIOS ${ }^{1}$
}

\author{
${ }^{1}$ Vertebrate Zoology Research Group, CIBIO, University of Alicante, Apdo. 99, E-03080, Alicante, SPAIN, e-mail: \\ Clara.Garcia@uv.es
}

García-Ripollés C., López-López P., Urios V. 2011. Ranging behaviour of non-breeding Eurasian Griffon Vultures Gyps fulvus: a GPS-telemetry study. Acta Ornithol. 46: 127-134. DOI 10.3161/000164511X625892

\begin{abstract}
Little is known about the spatial ecology and ranging behaviour of vultures in Europe. In this paper we used GPS satellite telemetry to assess home-ranges of eight non-breeding Eurasian Griffon Vultures in Spain, trying to answer the main questions on when (i.e. the time of the day), how far (i.e. hourly and daily distances) and where vultures range (i.e. home-range size). Results indicated that vultures ranged extensively mainly in areas where traditional stock-raising practices and pasturing were still common, also including some vulture restaurants, which were visited occasionally. Eurasian Griffon Vultures concentrated their hourly and daily movements in the middle of the day, when the availability of thermal updrafts was higher, favouring foraging activities. The overall foraging range, calculated as Minimum Convex Polygon (MCP) $\left(7419 \mathrm{~km}^{2}\right)$, or as $95 \%$ and $50 \%$ kernel contours $\left(4078 \mathrm{~km}^{2}\right.$ and $489 \mathrm{~km}^{2}$, respectively), was higher than those reported in previous studies. The precise knowledge of the ranging behaviour and spatial parameters is particularly important for the conservation of scavenger species inhabiting human-dominated areas where human activities may jeopardize vulture populations in the long term.
\end{abstract}

Key words: conservation, daily activity, home-range, satellite-tracking, Spain, spatial ecology

Received — July 2011, accepted — Nov. 2011

\section{INTRODUCTION}

To date, Spain holds more than $95 \%$ of the European population of the Eurasian Griffon Vulture Gyps fulvus, and still maintains one of the healthiest populations of the scavenger guild all over the world (Ferguson-Lees \& Christie 2001, Del Moral 2009). The Eurasian Griffon Vulture population has experienced an overall increase in the Spanish stronghold, where it has increased from 2283 to 25541 breeding pairs between the first censuses carried out in late 70s until present (Del Moral 2009). The species is globally and regionally catalogued as "Least Concern" (Del Moral 2009, BirdLife International 2011). Habitat loss, rural abandonment, intensification of farming practices, and rising of non-natural mortality caused by poisoning (Gangoso et al. 2009), pollutant ingestion (Hernández \& Margalida 2008, Lemus et al. 2008) and collision with wind-farms (Tellería 2009, Martínez-Abraín et al. 2012), are the main threats to vulture populations (GarcíaRipollés \& López-López 2011).
Traditionally, Spanish farmers have dumped organic remains of dead cattle in the so-called "vulture restaurants" or "supplementary feeding stations". Vulture restaurants are broadly distributed all over inner Spain, mainly close to traditional livestock areas, and are commonly located in remote regions (García-Ripollés et al. 2004, review in Donázar et al. 2009). Although there are geographic variations in the management procedures, vulture restaurants normally work all over the year (at least in the study area) and the contribution of carrion is continued, varying usually from weekly to fortnightly. However, since the outbreak of the neurodegenerative disease in cattle, Bovine Spongiform Encephalopathy (BSE), mandatory regulations of the European Union led to the temporary closure of existing vulture restaurants in order to avoid the likely risk of transmission to humans (the Creutzfeldt-Jakob disease). Consequently, owing to this temporal food shortage, the populations of scavengers seem to have been affected, with survival and breeding success being reduced 
(Camiña \& Montelío 2006, Martínez-Abraín et al. 2012).

The Eurasian Griffon Vulture is a long-lived species characterised by delayed maturity, longlifespan and low reproductive rates (FergusonLees \& Christie 2001) and most of the studies have focused on breeding ecology of the species (e.g. Olea et al. 1999, López-López et al. 2004, GarcíaRipollés et al. 2005, Van Beest et al. 2008). However, little is known about ranging behaviour and spatial parameters. This is key to help managers to improve conservation measures aimed at combining the maintenance of scavengers' populations with sanitary legislation, as well as for the installation of wind-farms, which also constitute a potential source of mortality (Tellería 2009, Martínez-Abraín et al. 2012). Traditional ringing schemes and radio-tracking studies have shown that the species ranges extensively, particularly juveniles (e.g. Elosegui \& Elosegui 1977, Bahat et al. 1993, Griesinger 1998, Bahat 2001, Gil et al. 2009, Xirouchakis \& Andreou 2009), but accurate data about Eurasian Griffon Vulture's spatial ecology and ranging behaviour still remains unknown (Mundy et al. 1992, Donázar 1993, Ferguson-Lees \& Christie 2001). The first available data regarding Eurasian Griffon Vulture ranging behaviour were based on Argos satellite tracking of one juvenile tracked experimentally in the early 90 's, when satellite tracking was still a promising method (Berthold et al. 1991). This bird was tracked over a two-month period from late September to late November 1990, covering a total distance of 2000 $\mathrm{km}$ from the breeding ground in the Pyrenees to the eastern coast of Spain. Since then, only a few papers based on Argos satellite tracking of Eurasian Griffon Vultures have been published (Bahat et al. 2001, McGrady \& Gavashelishvili 2006). However, to the best of our knowledge, the available literature does not report the satellite tracking of Eurasian Griffon Vultures based on accurate Global Positioning System (GPS) locations so far. The main improvement of GPS satellite tracking is that it provides more accurate locations than Argos technology (Argos 2011), and therefore it gives rise to address old questions which still remain unsolved.

This paper presents data of GPS satellite tracking of eight Eurasian Griffon Vultures in Spain. Our aim is to provide information on ranging behaviour of Eurasian Griffon Vultures, trying to answer the main questions on when (i.e. the time of the day), how far (i.e. hourly and daily distances) and where vultures range (i.e. homerange size). We also provide information about frequently-used roosting places and their relationship with the vulture restaurants located in the study area. Finally, we discuss our results in relation to previous studies about banded and tracked birds.

\section{METHODS}

Seven adults and one subadult Eurasian Griffon Vultures were equipped with satellite platform transmitter terminals (PTTs) (Table 1). Birds were aged according to plumage characteristics (Ferguson-Lees \& Christie 2001). Blood samples were not taken during the vulture trapping so molecular sexing could not be carried out. All birds were non-breeders according to fieldwork. Six birds were captured on April 2007 and two birds were captured on October 2009 in a vulture restaurant $\left(40^{\circ} 33^{\prime} \mathrm{N}, 0^{\circ} 13^{\prime} \mathrm{W}\right)$ located in the Cinctorres district (Castellón province, East of Spain), using a remotely activated cage built ad hoc. In all cases, a Microwave Telemetry's $70 \mathrm{~g}$ solar-powered GPS-PTT was fixed to their backs using a Teflon harness sewed with a cotton ribbon to allow birds to lose the harness after the end of the PTT's life cycle (García-Ripollés et al. 2010). The PTTs were programmed to record one GPS position per hour from 07:00 to 21:00 hours (local time) for the whole annual period.

Hourly flight distances were obtained by calculating the straight-line distance between consecutive locations (segments) that were separated by one hour within the same day. Daily activity (i.e. a measure of daily activity) was computed as the frequency of segments for which an effective movement was recorded, this is, movements further away of the nominal accuracy of the GPS $( \pm 25 \mathrm{~m})$. We also calculated the daily distances covered by the Eurasian Griffon Vultures as the sum of straight-line distances covered between consecutive locations in the same day. Since the daily distance correlates strongly with the number of fixes recorded $\left(\mathrm{R}^{2}=0.21, \mathrm{p}<\right.$ $0.0001)$, we only used days with at least $(\mathrm{N}+1)$ locations for computing, where $\mathrm{N}$ is the median number of locations separated by one hour obtained for each day (in our case $\mathrm{N}=5$ ) (Urios et al. 2010). We used the non-parametric KruskalWallis test to explore hourly and daily differences in distances covered among individuals (Sokal \& Rohlf 1994). 
We estimated the vultures' home-range by means of a kernel density approach (Kenward 2001). Home-range analyses were performed with the "Animal Movement" extension for Arcview 3.2 (Hooge \& Eichenlaub 1997). Fixed 95\% and 50\% kernel density contours were calculated to estimate home-ranges (Fieberg 2007). Least Squares Cross Validation method (LSCV) was used to calculate the smoothing parameter $(h)$ (Silverman 1986). Additionally, we also calculated the overall median foraging range as the Minimum Convex Polygon (MCP) encompassing all GPS locations obtained for each bird (Worton 1989). These estimates were computed to facilitate comparisons between studies and regions (Vasilakis et al. 2008). Individual's data were partitioned among seasons of the year (i.e. spring, summer, autumn and winter). Then, we used a Kruskal-Wallis test to explore differences: (i) among seasons of the year, pooling data of all individuals; and (ii) among seasons of the year within individuals (Sokal \& Rohlf 1994). Differences between age classes were not computed due to low sample size (six adults vs. one subadult). Statistical analyses were computed in Statistica 6.0. (StatSoft Inc, www. statsoft. com). Significance level was established at $\mathrm{p}<0.05$.

Nocturnal roosting places were obtained by filtering the early morning locations for each day (from 07:00 to 09:00 h). A roosting place was considered re-used when it was visited at least three times in non-consecutive days. The distance from frequently-used roosting places to the closest vulture restaurant was also computed. Cartography was elaborated in ArcMap 9.2 (ESRI Inc., www.esri.com).

\section{RESULTS}

During the study period a total of 2122 GPS locations were received (Table 1$)$. The average number of locations per bird was 265 (SD $=215$; range $=$ 82-662). Birds were tracked on average during 197 days $(S D=143$, range $=49-401)$, from April 2007 to September 2010. One bird (vulture \#1) was recovered dead on March 2009 in Castellón province (Spain). The other birds ceased transmission for unknown causes: four birds in Teruel province, one in Zaragoza, one in Ciudad Real and one in Castellón province. In two cases, the PTTs were found on the ground and were sent for refurbishment to the manufacturer. These PTTs were those fitted to the vultures \#7 and \#8 in 2009.

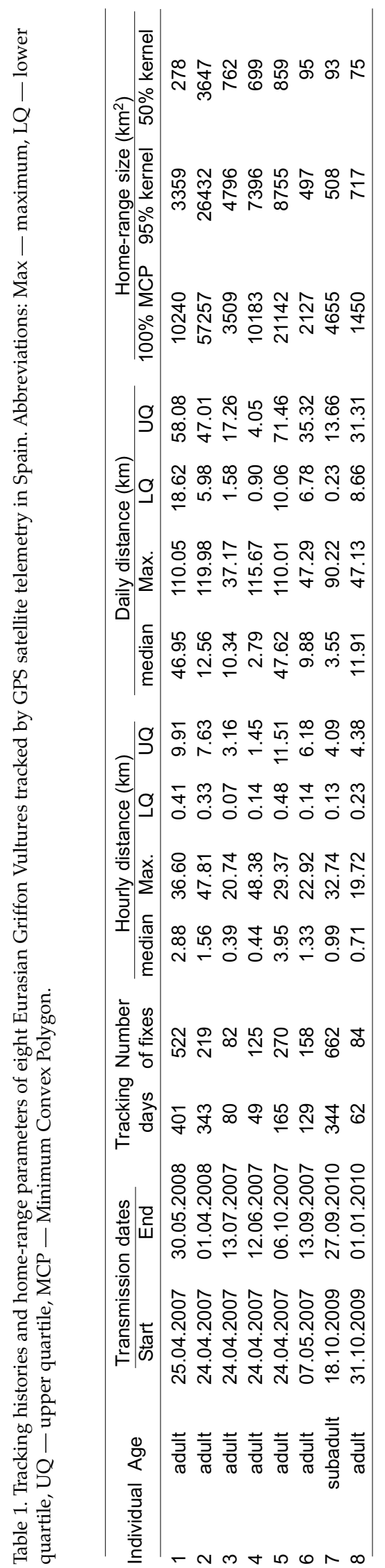


Eurasian Griffon Vultures covered median hourly distances ranging from 0.39 to $3.95 \mathrm{~km}$ (Table 1). The maximum distances covered in an hour ranged from 19.72 to $48.38 \mathrm{~km}$ (Table 1). There were significant differences in the hourly distances among individuals (Kruskal-Wallis test: $\mathrm{H}_{7885}=43.14, \mathrm{p}<0.001$ ). Although Eurasian Griffon Vultures occasionally perform long-distance movements, $68.5 \%$ of the hourly movements did not exceed $5 \mathrm{~km}$ and only $10.7 \%$ were larger than $15 \mathrm{~km}$ (Fig. 1a). The median daily distances ranged from 2.79 to $47.62 \mathrm{~km}$, and the maximum distances covered in a day ranged from 37.17 to $119.98 \mathrm{~km}$ (Table 1). There were significant differences in the daily distances among individuals (Kruskal-Wallis test: $\mathrm{H}_{7,137}=39.68, \mathrm{p}<0.001$ ).
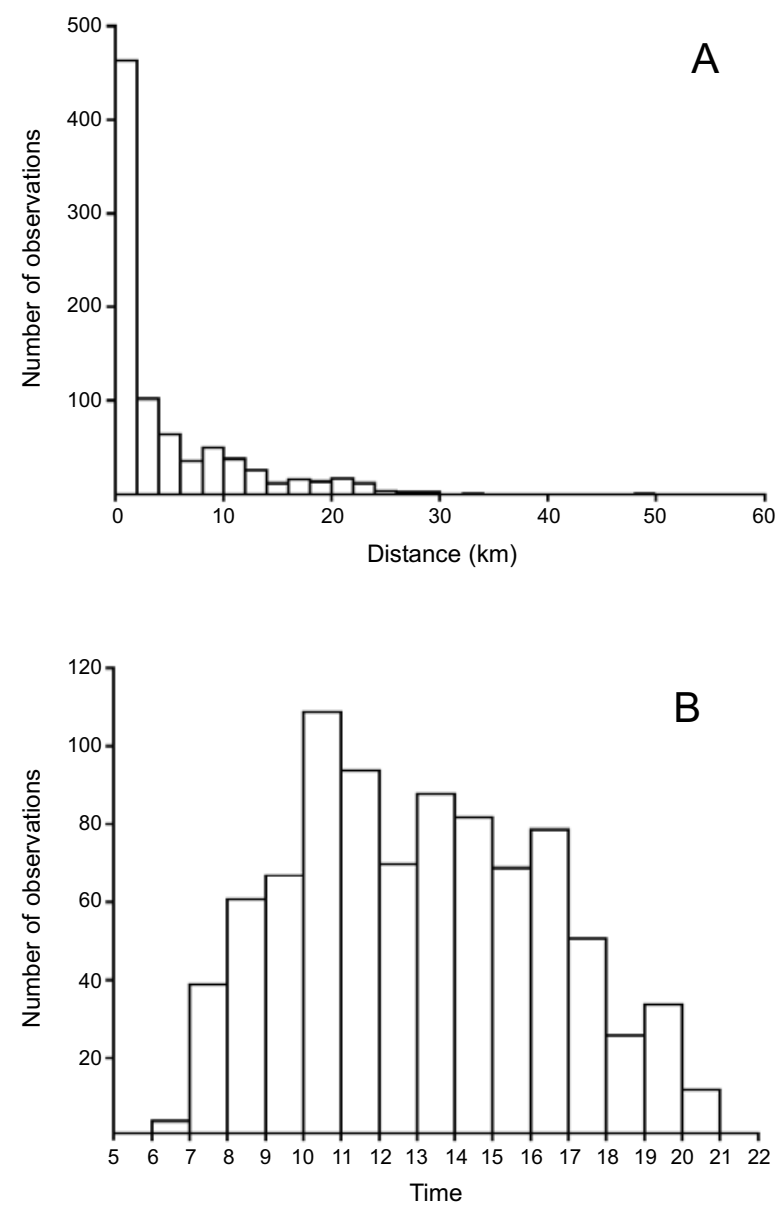

Fig. 1. Hourly distance (A) and daily activity (B) of the movements of eight Eurasian Griffon Vultures recorded in Spain by means of GPS satellite telemetry. Time is given in hours according to Spanish local time (GMT + 2 in summer; GMT + 1 during the rest of the year). For the analyses of the hourly and daily distances the data of all individuals were pooled together.
Regarding daily activity, both the longest movements and the largest proportion of longdistance movements $(66.78 \%)$ took place between 11:00 and 17:00 $\mathrm{h}$, corresponding with the peak of daily activities (Fig. 1b). There were individual differences in the daily activity (Kruskal-Wallis test: $\left.\mathrm{H}_{7,885}=14.38, \mathrm{p}=0.045\right)$. Although nocturnal data were not recorded, the locations obtained in early morning and in late evening suggested no nocturnal movement.

The overall median foraging range, calculated as $\mathrm{MCP}$, for the eight Eurasian Griffon Vultures was $7419 \mathrm{~km}^{2}$ (inter-quartile range, IQR: 2818$15691 \mathrm{~km}^{2}$ ). For the $95 \%$ and $50 \%$ kernel contours, medians were $4078 \mathrm{~km}^{2}$ (IQR: $613-8075 \mathrm{~km}^{2}$ ) and $489 \mathrm{~km}^{2}$ (IQR: $94-810 \mathrm{~km}^{2}$ ), respectively (Table 1). With data of all individuals pooled $(\mathrm{n}=8)$, there were no differences in home-range size (according to 50\% kernel) among seasons of the year (Kruskal-Wallis test: $\mathrm{H}_{3,20}=3.61, \mathrm{p}=0.307$ ). Nevertheless, significant differences in seasonal home-ranges (according to 50\% kernel) were found among individuals (Kruskal-Wallis test: $\mathrm{H}_{7,20}=15.72, \mathrm{p}=0.028$ ).

The seasonal overlap in home-range within individuals (according to 50\% kernel) was low or inexistent (median $=0.00$, IQR: $0.00-4.27$ ) for seven individuals (vultures \#1-6 and \#8). In only one case (vulture \#7), the seasonal overlap in home-range was high, ranging from $4.56 \%$ to 86.13\% (median $=23.62$, IQR: 5.12-37.82).

There were 16 vulture restaurants located across the area encompassed within the vulture home-ranges, 12 located in Teruel province and 4 in Castellón province. The average distance among them was $71.53 \mathrm{~km}(\mathrm{SD}=39.20$, range $=$ 10.88-195.45). Eurasian Griffon Vultures made use of many different roosting places, but re-used frequently an average of four roosting places per bird (range $=1-10$ ). The average linear distance from these frequently-used roosting places to the closest vulture restaurant was $14.05 \mathrm{~km}(\mathrm{SD}=$ 10.78 , range $=1.14-54.55, \mathrm{n}=32$ ) and did not differ among birds (Kruskal-Wallis test: $\mathrm{H}_{7,32}=9.75$, $\mathrm{p}=0.203)$. In some cases, satellite-tracking data showed how vultures were temporarily linked to a particular vulture restaurant, not always matching with food availability (authors' personal observation). This was for example the case of the subadult vulture \#7, which remained long periods in the nearby of a particular vulture restaurant, without getting more than $1.5 \mathrm{~km}$ away from it. 


\section{DISCUSSION}

Median and maximum daily distances obtained for the eight Eurasian Griffon Vultures tracked by GPS satellite telemetry were similar to those reported in previous reports. For example, Glutz et al. (1971) reported daily distances between 50-60 km; Elosegui \& Elosegui (1977) between 25-75 km; Arroyo \& Garza (1995) between 20-80 $\mathrm{km}$; and Gil et al. (2009) between 2-24 km. It should be taken into account that these studies were based on direct observations, banding recoveries or terrestrial radio-tracking, which may lead to some biases in the estimates of home-ranges and spatial parameters (Bosch et al. 2010). Our results show that birds wait until central hours of the day when thermal updrafts are available, thus concentrating their daily movements between 11:00 and 17:00 h. In fact, other studies have reported that Eurasian Griffon Vultures allocated an average of $7.6 \pm 1.1$ hours/ day to food searching (Xirouchakis \& Andreou 2009). Eurasian Griffon Vultures combine soaring on thermals to gain height, alternating with periods of gliding for displacing (Spaar 1997). The use of thermals has also been reported to account for higher flying activity at midday in a number of raptor species (Spaar 1997, García-Ripollés et al. 2010).

Our results indicate that vultures range extensively across vast regions in Eastern Spain, encompassing large areas of the Maestrazgo region, between Teruel and Castellón provinces (Fig. 2). Traditional stock-raising practices and herding are still common in this region (López-López et al. 2004, García-Ripollés et al. 2005), which still preserves a large portion of the Eurasian Griffon Vulture population in Spain (Del Moral 2009). It has been suggested that the maintenance of traditional farming practices and pasturing is key to preserve the species across its distribution range (Olea \& Mateo-Tomás 2009). Although occasional$\mathrm{ly}$, in certain regions, the presence of wild ungulates could constitute an important food resource for avian scavengers (Margalida et al. 2011), their role as a food source in the vulture diet remains largely unknown in our study area. The lack of a much higher sample size, the limited duration of PTTs' batteries and the unknown sex of the individuals constitute limitations preventing us from deeper analyses. For example, the effects of how the temporal closure of some vulture restaurants (from April 2006 to October 2007, in the case of
Castellón province) affected ranging behaviour did not led to conclusive results, according to a preliminary analysis. In fact, at least one vulture restaurant continued dumping carcasses illegally (author's personal observation), thus allowing food availability in the study area.

The overall foraging range, as calculated as MCP, or as according to $95 \%$ and $50 \%$ kernels, was higher than those reported in previous studies. For example, Xirouchakis \& Andreou (2009) reported range sizes ranging from 390 to $1300 \mathrm{~km}^{2}$ (according to $100 \% \mathrm{MCP}$ ), and $380 \mathrm{~km}^{2}-64 \mathrm{~km}^{2}$ according to $95 \%$ and $50 \%$ kernel, respectively; whereas Gil et al. (2009) reported maximum home-ranges between $23-161 \mathrm{~km}^{2}$. By contrast, the home-range size reported here was lower than those reported for satellite-tracked Cape Vultures Gyps coprotheres in Namibia, which were $21320 \mathrm{~km}^{2}$ for adults and $482276 \mathrm{~km}^{2}$ for juveniles (Bamford et al. 2007). Differences in home-range size could be explained by the availability of suitable habitat for foraging, individual's age and sex, as well as the method used for tracking. In fact, Eurasian Griffon Vultures usually forage within a few kilometres from their usual roosting places $(14.05 \mathrm{~km}$ in this study), which were very similar to the distances reported in Gil et al. (2009) $(14.3 \mathrm{~km})$, and Xirouchakis \& Andreou (2009) (ca. $15 \mathrm{~km}$ ). Similar results have been reported for other vulture species such as the Cape Vultures $(<20 \mathrm{~km})$ (Bamford et al. 2007), or Cinereous Vulture Aegypius monachus (ca. $30 \mathrm{~km}$ in the case of breeding individuals) (Moreno-Opo et al. 2010). Occasionally, Eurasian Griffon Vultures perform long-distance movements for foraging, particularly dispersing juveniles and subadult birds (Bahat 2001, McGrady \& Gavashelishvili 2006). The longest displacement recorded in this study was the case of one adult vulture which moved from the Maestrazgo region (eastern Spain) to a vulture restaurant located in the Ciudad Real province (central Spain), $380 \mathrm{~km}$ away from the tagging site (vulture \#2; Fig. 2). The displacement was carried out in 12 days, remaining in the area at least eight days until transmission signal ceased eventually.

Finally, this study provides a first preliminary insight of the spatial ecology of the Eurasian Griffon Vulture. Ongoing research projects will grant complementary information about breeding individuals and inter-sexual differences that will improve our understanding of the spatial ecology and behaviour of scavenger species. 

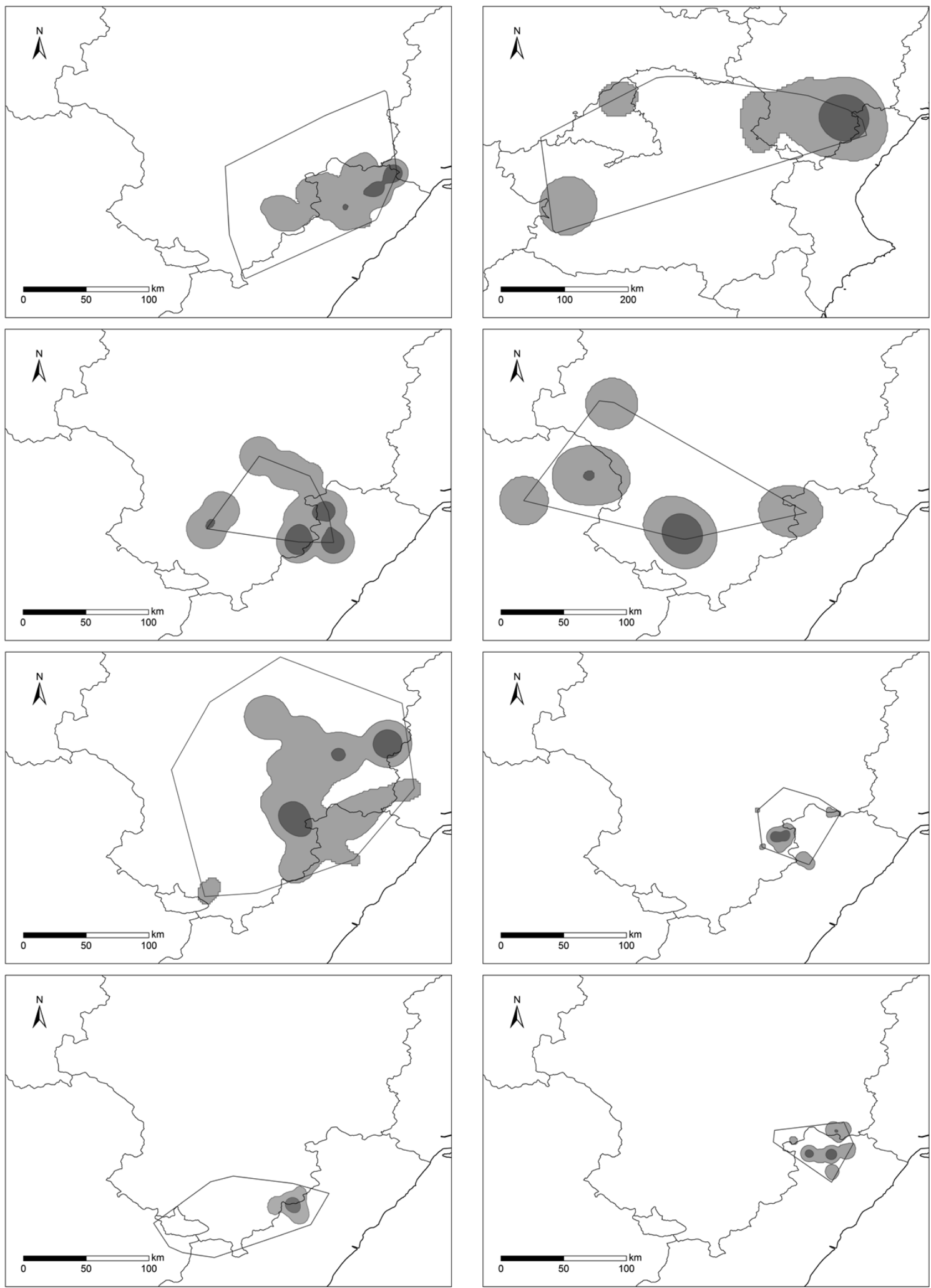

Fig. 2. Ranging behaviour of eight Eurasian Griffon Vultures according to the kernel home-range analysis. The Minimum Convex Polygon (solid line), 95\% kernel (pale grey) and 50\% kernel (dark grey) are shown. Note the scale invariance to allow comparison of range size among individuals (except for vulture \#2). Spanish Administrative units are shown. Individuals (1-8) are shown from top to down and from left to right. 


\section{ACKNOWLEDGEMENTS}

Funding for the purchase of PTTs was provided by RENOMAR, Energías Renovables Mediterráneas, S.A. The consultancy PyG Estructuras Ambientales S.L. through the regional administration (Conselleria de Medi Ambient, Generalitat Valenciana) kindly provided the satellite telemetry data. Thanks are due to A. Martínez and E. Servera for their valuable help. F. J. Fernández and J. Ortega kindly provided bibliographic material. We would like to thank the "Servicio de Biodiversidad" of the Conselleria de Medi Ambient, especially J. Jiménez and M. Surroca for their help in bird trapping and PTTs fixing. R. Limiñana and an anonymous referee made valuable comments on a previous draft of this paper. P. López-López is supported by a "Juan de la Cierva" postdoctoral grant of the Spanish Ministry of Economy and Competitiveness (reference JCI-2011-09588).

\section{REFERENCES}

Argos 2011. Argos User's Manual. CLS/Service Argos, Toulouse.

Arroyo B., Garza V. 1995. [Radio-tracking of Eurasian Griffon Vultures (Gyps fulvus) in the Hoces del Río Duratón Natural Park]. Consejería de Medio Ambiente y Ordenación del Territorio, Junta Castilla y León.

Bahat O. 2001. Conservation of threatened raptor populations in Israel. In: Leshem Y., Froneman A., Mundy P., Shamir H. (eds). Wings over Africa. Proceedings of the International Seminar on Bird Migration: Research, Conservation, Education and Flight Safety. Tel Aviv Univ., pp: 177189.

Bahat O., Hatzoffe O., Kaplan A., Woodley B. 2001. Foraging range and movements of Griffon vultures (Gyps fulvus) in Israel, as determined by satellite tracking. Proceedings of the $4^{\text {th }}$ Eurasian Congress on raptors. Dońana Biological Station, Raptor Research Foundation, Seville, pp. 1112.

Bahat O., Kaplan A., Baidatz Y., Kaplan L., Choshniak I., Houston D. 1993. Radio-tracking a juvenile Griffon Vulture (Gyps fulvus) in the north of Israel preliminary results. Israel J. Zool. 39: 47-77.

Bamford A. J., Diekmann M., Monadjem A., Mendelsohn J. 2007. Ranging behaviour of Cape Vultures Gyps coprotheres from an endangered population in Namibia. Bird Conserv. Int. 17: 331-339.

Berthold P., Griesinger J., Nowak E., Querner U. 1991. [Satellite telemetry of Griffon Vulture (Gyps fulvus) in Spain]. J. Ornithol. 32: 327-329.

BirdLife International 2011. Species factsheet: Gyps fulvus. http://www.birdlife.org, accessed 09/11/2011.

Bosch R., Real J., Tintó A., Zozaya E. L., Castell C. 2010. Homeranges and patterns of spatial use in territorial Bonelli's Eagles Aquila fasciata. Ibis 152: 105-117.

Camiña A., Montelío E. 2006. Griffon vulture Gyps fulvus food shortages in the Ebro Valley (NE Spain) caused by regulations against bovine spongiform encephalopathy (BSE). Acta Ornithol. 41: 7-13.
Del Moral J. C. 2009. [The Eurassian Griffon Vulture in Spain. Breeding population in 2008 and census technique]. Technical report $n^{\circ} 30 . S E O /$ BirdLife, Madrid.

Donázar J. A. 1993. [The Iberian Vultures. Biology and Conservation]. Reyero, Madrid.

Donázar J. A., Margalida A., Campión D. (eds). 2009. [Vultures, feeding stations and sanitary legislation: a conflict and its consequences from the perspective of conservation biology]. Munibe 29 (Suppl.). Sociedad de Ciencias Aranzadi, San Sebastián.

Elosegui J., Elosegui R. 1977. [Displacements of Pyrenean Eurasian Griffon Vultures (Gyps fulvus)]. Munibe 1-2: 97-104.

Ferguson-Lees J., Christie D. A. 2001. Raptors: Birds of Prey of the World. A \& C Black Pub., Ltd., London.

Fieberg J. 2007. Kernel density estimators of home range: smoothing and the autocorrelation red herring. Ecology 88: 1059-1066.

Gangoso L., Álvarez-Lloret P., Rodríguez-Navarro A. A. B., Mateo R., Hiraldo F., Donázar J. A. 2009. Long-term effects of lead poisoning on bone mineralization in vultures exposed to ammunition sources. Environ. Pollut. 157: 569-574.

García-Ripollés C., López-López P. 2011. Integrating effects of supplemental feeding, poisoning, pollutant ingestion an wind farms of two vulture species in Spain using a Population Viability Analysis. J. Ornithol. 152: 879-888.

García-Ripollés C., López-López P., García-López F. 2004. Management and monitoring of a vulture restaurant in Castellón province, Spain. Vulture News 50: 5-14.

García-Ripollés C., López-López P., García-López F., Aguilar J. M., Verdejo J. 2005. Modelling nesting habitat preferences of Eurasian Griffon vulture Gyps fulvus in eastern Iberian Peninsula. Ardeola 52: 287-304.

García-Ripollés C., López-López P., Urios V. 2010. First description of migration and wintering of adult Egyptian vultures Neophron percnopterus tracked by GPS satellite telemetry. Bird Study 57: 261-265.

Gil J. A., Lagares J. L., Alcántara M. 2009. [Radio-telemetry of the Eurasian Griffon Vulture (Gyps fulvus) in the Eastern Iberico System (Aragón-Spain)]. Teruel 92: 137-164.

Griesinger J. 1998. Juvenile dispersion and migration among Griffon Vultures Gyps fulvus in Spain. In: Chancellor R. D., Meyburg B. -U., Ferrero J. J. (eds). Holarctic Birds of Prey. ADENEX-WWGBP, pp. 613-621.

Glutz Von Blotzheim U., Bauer K., Bezzel E. 1971. [Handbook of the Birds of Central Europe]. Vol. 4: Falconiformes. Academic Verlagasgesellscheft, Frankfurt am Main.

Hernández M., Margalida A. 2008. Pesticide abuse in Europe: effects on the Cinereous vulture (Aegypius monachus) population in Spain. Ecotoxicology 17: 264-272.

Hooge P. N., Eichenlaub B. 1997. Animal movement extension to Arcview. ver. 2.0. Alaska Science Center - Biological Science Office, U.S. Geological Survey, Anchorage, AK, USA.

Kenward R. E. 2001. A manual for wildlife radio tagging. Academic Press, London.

Lemus J. A., Blanco G., Grande J., Arroyo B., García-Montijano M. 2008. Antibiotics threaten wildlife: Circulating quinolone residues and disease in avian scavengers. PLoS ONE 3: e1444.

López-López P., García-Ripollés C., Verdejo J. 2004. Population status and reproductive performance of Eurasian Griffons (Gyps fulvus) in Eastern Spain. J. Raptor Res. 38: 350-356.

Margalida A., Colomer M. A., Sanuy D. 2011. Can wild ungulate carcasses provide enough biomass to maintain avian scavenger populations? An empirical assessment using a bio-inspired computational model. PLoS ONE 6(5): e20248. 
Martínez-Abraín A., Tavecchia G., Regan H. M., Jiménez J., Surroca M., Oro D. 2012. Effects of wind farms and food scarcity on a large scavenging bird species following an epidemic of bovine spongiform encephalopathy. J. Appl. Ecol. 49: 109-117.

McGrady M., Gavashelishvili A. 2006. Tracking Vultures from the Caucasus into Iran. Podoces 1: 21-26.

Moreno-Opo R., Arredondo Á., Guil F. 2010. Foraging range and diet of Cinereous vulture Aegypius monachus using livestock resources in central Spain. Ardeola 57: 111-119.

Mundy P., Butchart D., Ledger J., Piper S. 1992. The vultures of Africa. Acorn, Randburg. Academic Press, London.

Olea P. P., García J., Falagán J. 1999. [Griffon Vulture Gyps fulvus range expansion: population size and reproductive parameters of a recently established population in northwestern Spain]. Ardeola 46: 81-88.

Olea P. P., Mateo-Tomás P. 2009. The role of traditional farming practices in ecosystem conservation: The case of transhumance and vultures. Biol. Conserv. 142: 1844-1853.

Silverman B. W. 1986. Density estimation for statistics and data analysis. Chapman and Hall, London.

Spaar R. 1997. Flight strategies of migrating raptors; a comparative study of interspecific variation in flight characteristics. Ibis 139: 523-535.

Sokal R. R., Rohlf F. J. 1994. Biometry: the principles and practice of statistics in biological research. $3^{\text {rd }}$ edition. Freeman, New York.

Tellería J. L. 2009. Wind power plants and the conservation of birds and bats in Spain: a geographical assessment. Biodivers. Conserv. 18: 1781-1791.

Urios V., López-López P., Limiñana R., Godino A. 2010. Ranging behaviour of a juvenile Bearded Vulture (Gypaetus barbatus meridionalis) in South Africa revealed by GPS satellite telemetry. Ornis Fennica 87: 114-118.

Van Beest F., van den Bremer L., de Boer W. F., Heitkönig I. M A., Monteiro A. E. 2008. Population dynamics and spatial distribution of Griffon Vultures (Gyps fulvus) in Portugal. Bird Conserv. Int. 18: 102-117.

Vasilakis D. P., Poirazidis K. S., Elorriaga J. N. 2008. Range use of a Eurasian black vulture (Aegypius monachus) population in the Dadia-Lefkimi-Soufli National Park and the adjacent areas, Thrace, NE Greece. J. Nat. Hist. 42: 355-373.

Worton B. J. 1989. Kernel methods for estimating the utilization distribution in home-range studies. Ecology 70: 164-168.

Xirouchakis S. M., Andreou G. 2009. Foraging behaviour and flight characteristics of Eurasian griffons Gyps fulvus in the island of Crete, Greece. Wildlife Biol. 15: 37-52.
STRESZCZENIE

[Wielkość areałów żerowiskowych nielęgowych sępów płowych]

Celem badań było określenie jak duże są areały osobnicze sępów płowych, oraz $\mathrm{w}$ jakich porach dnia, i jak daleko mogą przemieszczać się te ptaki, zarówno w ciągu jednej godziny jak i poszczególnych dni. Tak dokładne informacje są istotne dla planowania działań ochronnych tego gatunku, szczególnie na terenach poddanych działalności człowieka. Określano także położenie najczęściej używanych miejsc noclegowych względem tzw. "restauracji dla sępów” - miejsc, w których wyrzucana jest padlina zwierząt gospodarskich. Ptaki chwytano $w$ jednym $z$ takich miejsc, znajdującym się w prowincji Castellon, we wschodniej Hiszpanii. Łącznie ośmiu ptakom założono nadajniki satelitarne GPS. Nadajniki były zaprogramowane na zapisywanie jednej lokalizacji na godzinę, pomiędzy 7.00 a 21.00 czasu lokalnego. Wszystkie ptaki były nielęgowe w okresie zbierania danych.

Wyniki wskazują, że sępy przemieszczają się po terenach, na których ma miejsce tradycyjny wypas i hodowla bydła oraz $\mathrm{w}$ miejscach gdzie wykładana jest padlina. Stwierdzono, że maksymalna odległość przemieszczenia się osobnika w ciągu godziny wyniosła $48 \mathrm{~km}$, choć średnio było to $0.39-3.95 \mathrm{~km}$, zależnie od osobnika (Tab. 1). 68.5\% przemieszczeń $\mathrm{w}$ ciągu godziny nie było dłuższe niż $5 \mathrm{~km}$ (Fig. 1A), 66.8\% przemieszczeń zanotowano pomiędzy 11.00 a 17.00 (Fig. 1B), kiedy dostępność ciepłych prądów wstępujących jest wysoka. Średnia wielkość areałów żerowiskowych wynosiła $7419 \mathrm{~km}^{2}$ (Tab. 1), a nakładanie się areałów było dość niskie (Fig. 2). Najdalszy przelot wy-niósł $380 \mathrm{~km}$ od miejsca złapania (Fig. 2). Na badanym terenie zanotowano łącznie 16 restauracji dla sępów. Średnia odległość między nimi a miejscami wykorzystywanymi najczęściej na nocleg wynosiła ok. $14 \mathrm{~km}$. 